\title{
Cytokine effects on pepsinogen secretion from human peptic cells
}

\author{
M T Serrano, A I Lanas, S Lorente, R Sáinz
}

\begin{abstract}
Background-Different cytokines, including epidermal growth factor (EGF) and interleukin $1 \beta$ (IL 1ß), participate in the pathogenesis of gastric mucosal damage and repair by means of different mechanisms that are either paracrine or autocrine in nature.
\end{abstract}

Aims-To study whether EGF and IL $1 \beta$ affect pepsinogen secretion in vitro.

Methods-Dispersed human peptic cells were prepared from endoscopically obtained biopsy specimens after collagenase digestion, mechanical disruption, and density gradient centrifugation.

Results-EGF dose dependently increased basal pepsinogen secretion and mitogenic concentrations ( $(0.1 \mathrm{nM})$ of EGF induced submaximal stimulation. Similar effects were observed with transforming growth factor $\alpha$. EGF effects on pepsinogen secretion were in addition to that induced by CCK-OP and db-cAMP stimulated pepsinogen secretion. EGF stimulated pepsinogen secretion was completely inhibited by a human immunospecific EGF receptor antibody and reduced by both genistein and tyrphostin-25, two different tyrosine kinase inhibitors. IL $1 \beta$ does not affect basal, CCK-OP or acetylcholine stimulated pepsinogen secretion. However, IL $1 \beta$ dose dependently inhibited db-cAMP and histamine stimulated pepsinogen secretion. Conclusions-These results show that both EGF and IL $1 \beta$ modulate human pepsinogen secretion in vitro and suggest that the paracrine effects of these cytokines on pepsinogen secretion might be involved in some pathological conditions of damage and inflammation of the gastric mucosa.

(Gut 1997; 40: 42-48)

Keywords: epidermal growth factor, tyrosine-kinase, interleukin 1, pepsinogen.

Service of

Gastroenterology, Hospital Clínico

Universitario,

Zaragoza, Spain

M T Serrano

A I Lanas

$S$ Lorente

R Sáinz

Correspondence to: Dr A I Lanas,

Servicio de Aparato

Digestivo

Hospital Clínico

Universitario,

50009 Zaragoza, Spain

Accepted for publication 28 August 1996 conditions such as peptic ulceration and inflammation. ${ }^{12}$ The involvement of cytokines in the peptic ulcer process has been reinforced by current data on Helicobacter pylori infection of the human gastric antrum mucosa. ${ }^{3}$ The complexity of the mechanisms involved in these conditions and the multiple biological actions of these peptides make further studies necessary to understand the role of cytokines in the regulation of gastric secretion and to establish potential pathophysiological bases for new therapeutic strategies. Furthermore, a potential role for the immune system in gastric acid secretion and peptic ulcer disease was suggested by Mezey and Palkovits. ${ }^{4}$ These authors found receptors for acetylcholine, histamine, gastrin, and dopamine in macrophages and IgA bearing plasma cells from the lamina propia of the gastric mucosa suggesting that these cells may be the targets of drugs that inhibit gastric acid secretion. The biology of these factors differs somewhat from classic hormones as neither the sites of synthesis nor the sites of actions are restricted to defined tissues. $^{56}$ Many growth factors and interleukins operate in a paracrine fashion, and, in some instances, their actions are autocrine in nature. In this way, in vitro studies seem necessary to better understand the effects of these peptides in the control of gastric functions including acid and pepsinogen secretion. ${ }^{7}$ Furthermore, this approach has the advance over in vivo animal models insofar as the concentrations of the test substances can be controlled precisely and interactions with other organs and cell types can be eliminated.

Unfortunately, current data on the effects of these factors in gastric secretion are mostly limited to experiments measuring acid secretion in different in vivo animal models, and, of all cytokines studied, both epidermal growth factor (EGF) and interleukin 1 (IL 1) have been shown to affect gastric secretion by inhibiting acid secretion in this type of studies. ${ }^{8}{ }^{9}$ However, although available information provides sufficient evidence that the intramucosal activation of acid proteases, mainly pepsinogens, plays a major part in peptic diseases of the upper gastrointestinal tract, ${ }^{1}$ there are no data on the potential effects of cytokines on pepsinogen secretion by the stomach. Moreover, many of the actions described for different factors on gastric secretion are species specific, which indicates that data from one species cannot be fully extrapolated to others (for example, humans). ${ }^{10}$ In this study we have examined in vitro the effects of EGF and IL $1 \beta$ on pepsinogen secretion by means of dispersed human peptic cells obtained from endoscopic biopsy specimens.

\section{Methods}

MATERIALS

Chemicals were obtained from the following sources: bovine serum albumin (fraction V), 
acetylcholine (ACh), histamine, db-cAMP, cholecystokinin-8 (CCK-OP), HEPES, percoll, crystalline porcine pepsinogen, soybean trypsin inhibitor, ethylene glycol tetraacetic acid (EGTA) and glucose from Sigma Chemical Co, (St Louis, MO); human rEGF and TGF $\alpha$ from Calbiochem (La Jolla, CA); the antibody against the hEGF receptor from Oncogene Science (Uniondale, NY); collagenase (Type IV) from Worthington Biochemical Corp (Freehold, NJ); bovine haemoglobin from Gibco Diagnostics, (Madison, WI). Human recombinant interleukin $1 \beta$ was obtained from two different sources. Most experiments were performed with that obtained from Calbiochem (La Jolla, CA). However, in the experiments performed in combination with db-cAMP the interleukin $1 \beta$ used was from Boehringer Mannheim (Mannheim, Germany).

Unless otherwise stated, the standard Ringer solution contained $82.2 \mathrm{mM} \mathrm{NaCl}$, $4.0 \mathrm{mM} \mathrm{KCl}, 1.8 \mathrm{mM} \mathrm{CaCl}_{2}, 0.8 \mathrm{mM} \mathrm{MgCl}_{2}$, $0.8 \mathrm{mM} \mathrm{NaSO}_{4}, 17.8 \mathrm{mM} \mathrm{NaHCO}_{3}, 0.8 \mathrm{mM}$ $\mathrm{NaH}_{2} \mathrm{PO}_{4}, 11.5 \mathrm{mM}$ glucose, and $0.2 \%$ bovine serum albumin. The medium was equilibrated with $95 \% \quad \mathrm{O}_{2}-5 \% \quad \mathrm{CO}_{2}$ and the $\mathrm{pH}$ was adjusted to $7 \cdot 25$. The $\mathrm{Ca}^{++}$low medium contained $0.1 \mathrm{mM} \mathrm{CaCl}$ and no $\mathrm{MgCl}_{2}$ and the $\mathrm{Ca}$ free medium contained no $\mathrm{CaCl}_{2}$ or $\mathrm{MgCl}_{2}$.

\section{Human material}

Gastric biopsy specimens were obtained from 83 patients undergoing upper gastrointestinal endoscopy (60 men). The mean (SD) age of this population was $42.8(1.51)(18-68)$. In 21 of these patients the endoscopy was normal, 20 had an active duodenal ulcer, 16 a healed duodenal ulcer, 13 oesophagitis, three a gastric ulcer, and 10 duodenitis or antritis without ulcer. Most of them were or had recently been taking $\mathrm{H}_{2}$ receptor antagonists, and the rest were taking antacids or free from any treatment. Helicobacter pylori status in the corpus of the stomach was not determined, but it was in the antrum (CLO-test, Delta West LTD, Canning Vale, Bentley, Australia) in 49 patients (positive in 42). No biopsy specimen's were obtained from patients who had recently used non-steroidal anti-inflammatory drugs (NSAIDs). The study was approved by the Institutional Review Board and written informed consent was obtained from all patients.

\section{STUDY DESIGN}

\section{Cell isolation}

Dispersed peptic cells were obtained from endoscopically obtained biopsy specimens after collagenase digestion, filtration, and density gradient centrifugation according to a method previously described. ${ }^{11}{ }^{12}$ This method yields a cell population with approximately $90 \%$ of peptic cells, $90 \%$ viable by trypan blue and flow cytometry.

Eight to 10 regular size punch biopsy specimens yielded approximately $10^{6}$ cells that were suspended in Ringer's solution under $95 \% \mathrm{O}_{2}-5 \% \mathrm{CO}_{2}$ atmosphere and refrigerated overnight. The next morning, the cells were allowed to warm at room temperature before they were used in experiments. No experiments were performed if cell viability was lower than $89 \%$ and experiments with a low total pepsinogen content were discarded.

\section{Experiments and calculations}

The warmed cells were re-suspended in fresh Ringer's solution and counted (haematocytometer). Aliquots of $10^{5}$ cells were then placed in $1.5 \mathrm{ml}$ polypropylene test tubes containing the appropriate agents and incubated in a shaking water bath under an atmosphere of $95 \% \mathrm{O}_{2}-5 \% \mathrm{CO}_{2}$ at $37^{\circ} \mathrm{C}$ for different periods of time. In general, cells from a single patient were sufficient for nine to 11 aliquots (including duplicates). If the experiment was high in the number of aliquots or samples, two sets of cells from two different people were put together. In this case $n=4$ means eight people. The experiments ended by centrifuging the tubes for 17 seconds at $14000 \mathrm{~g}$ and pipetting off the supernatants. An aliquot of the supernatant was assayed for pepsinogen activity using a modified Anson-Mirsky method using acid denaturated haemoglobin as the substrate as previously described. ${ }^{12}$ Secretory responses to stimuli were calculated in the output per unit time with basal output subtracted. The mean (SEM) basal rate of pepsinogen secretion in the experiments was $0.19(0.008)$ of total pepsinogen content per minute.

In some experiments carried out to study the role of calcium in basal or stimulated pepsinogen secretion, cells were washed once in calcium free Ringer's solution resuspended in calcium free Ringer's solution containing $0.5 \mathrm{mM}$ EGTA for three minutes to remove extracellular $\mathrm{Ca}^{++}$, washed again, and finally re-suspended in calcium free Ringer's solutions plus the drugs to be tested. When the antibody anti-EGF receptor (stock solution $=100 \mu \mathrm{g} / \mathrm{ml}$ ) was to be used, this was added one minute before the other agents. According to the manufacturer, the antibody is a mouse monoclonal $\operatorname{IgG}_{2 \mathrm{a}}$ with applications on in vivo studies and specificity for the cell surface domain of the human EGF receptor. The antibody inhibits the EGF binding to the EGF receptor and tumour formation in nude mice. ${ }^{13}$ Also, according to the manufacturer, one unit of IL $1 \beta$ was defined as the amount of IL $1 \beta$ that doubles the amount of ${ }^{3} \mathrm{H}$-thymidine incorporated by submitogenically activated (PHA, $1 \mu \mathrm{g} / \mathrm{ml}$ ) murine thymocytes.

Unless otherwise specified, the pepsinogen secretion obtained after different stimuli is expressed as the percentage of total cell pepsinogen content with basal secretion subtracted. Data are reported as mean (SEM) and the ' $n$ ' in each experiment is equal to the number of separate cell preparations. Analysis of variance (ANOVA) and Student's $t$ test for paired or unpaired data and either equal or unequal variances were used for statistical analysis and applied when appropriate. 


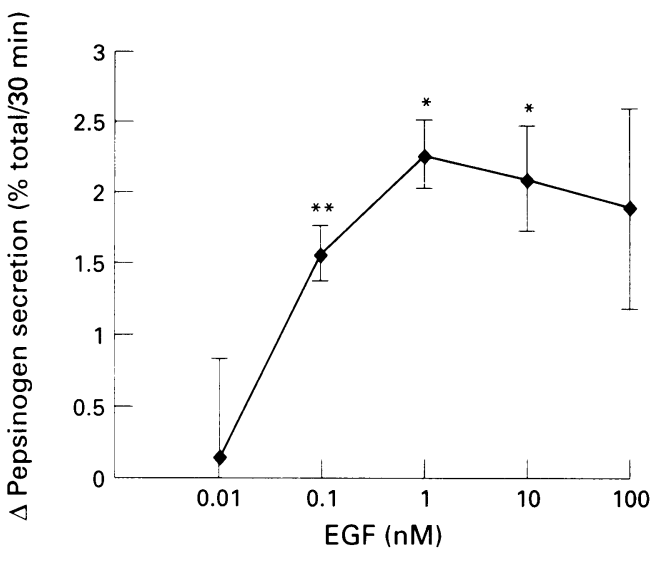

Figure 1: Effects of different concentrations of epidermal growth factor (EGF) on basal pepsinogen secretion from dispersed human peptic cells. EGF dose dependently stimulated basal secretion and maximal stimulation was achieved with $1 \mathrm{nM}$. $E C_{50}=7 \times 0.01 \mathrm{nM}$. Results are presented as means (SEM) of eight to 12 separate experiments. Basal secretion $=5 \cdot 20(0 \cdot 46) \%$.

\section{Results}

Effects of EGF on basal and stimulated pepsinogen secretion from isolated human peptic cells As previously shown, ${ }^{12}$ no differences were found in pepsinogen secretion from isolated cells in people with normal endoscopy or those with abnormal findings (see Methods). Therefore, results were obtained combining patients regardless of their pathological conditions. Most patients were $H$ pylori positives (42 of 49 in whom the status was determined), but no differences in pepsinogen secretion were found in experiments performed with cells obtained from $H$ pylori positive and $H$ pylori negative patients (basal secretion=5.7 $(0.39) \%$ v 5.94 $(0 \cdot 2) \%$ of total pepsinogen content).

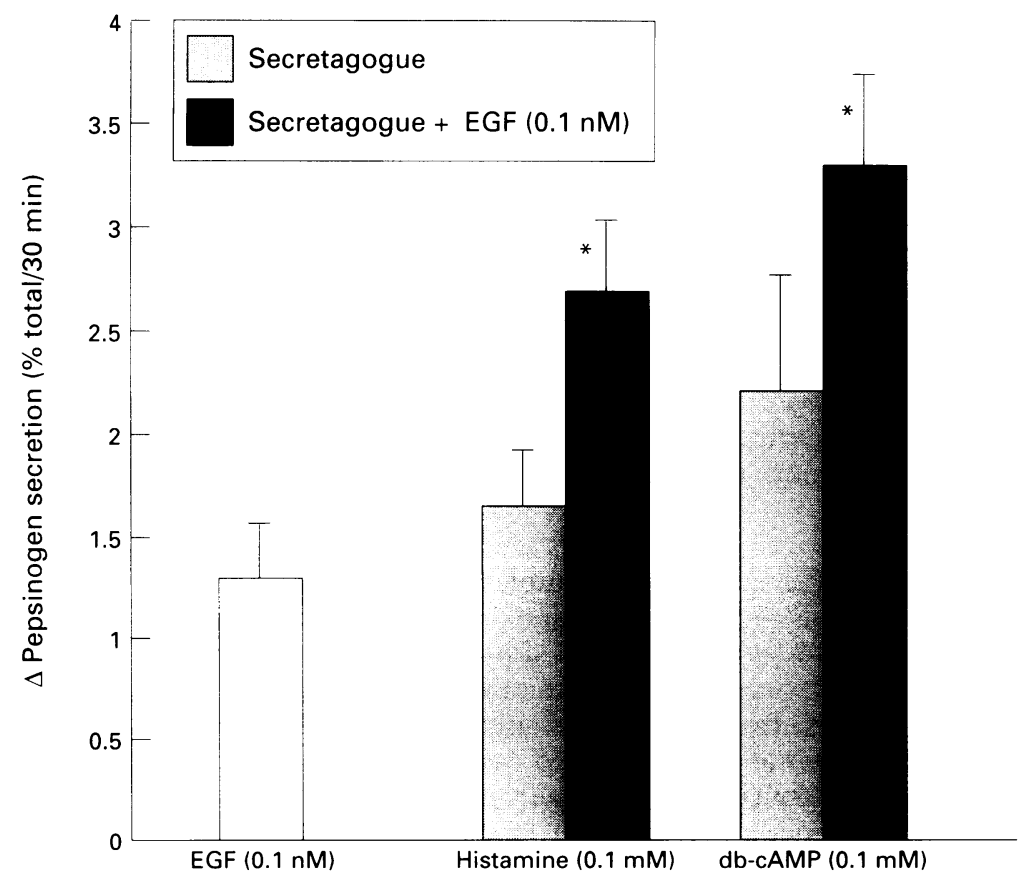

Figure 2: Epidermal growth factor (EGF) at $0 \cdot 1 \mathrm{nM}$ concentration significantly increased $\left({ }^{*} p<0.05\right)$ histamine and $d b-c A M P$ stimulated pepsinogen secretion from dispersed human peptic cells. The combination of EGF and these agents produced additive pepsinogen secretion responses. Histamine and $d b-c A M P$ stimulation was statistically significant $\left({ }^{\star} p<0 \cdot 05\right)$. Results are presented as means (SEM) of four separate experiments. Basal secretion $=5 \cdot 34(0 \cdot 67) \%$.
EGF dose dependently stimulated basal pepsinogen secretion from isolated human peptic cells (Fig 1). Maximal stimulation was achieved with $1 \mathrm{nM}(\Delta$ secretion $=2 \cdot 21(0 \cdot 25) \%)$. Concentrations of EGF $(0 \cdot 1 \mathrm{nM})$ that have proved to be mitogenic in different cellular systems, ${ }^{4}$ also significantly increased basal pepsinogen secretion. Apparently, the presence of previous $H$ pylori infection did not affect the EGF effect on pepsinogen secretion ( $\Delta$ secretion $=1 \cdot 2$ $(0.08) \%$ in $H$ pylori positive $v 1.3(0.15) \%$ in $H$ pylori negative after $0 \cdot 1 \mathrm{nM} \mathrm{EGF} ; \mathrm{n}=16$ and 6 respectively). When compared with other secretagogues, the EGF response was $46.3 \%$ of that induced by $0.1 \mu \mathrm{M}$ CCK, $84 \%$ of $0.01 \mathrm{mM}$ acetylcholine, and $52.5 \%$ of $\mathrm{mM}$ db-cAMP, similar to histamine, and $147 \%$ of $\mu M$ gastrin (Table I). This effect was calcium dependent because removal of extracellular calcium inhibited the stimulating effect of EGF on pepsinogen secretion $(0 \cdot 1 \mathrm{nM}=1 \cdot 3(0 \cdot 1) \%$ with $v 0.16(0.2) \%$ without calcium). A few experiments performed to evaluate the effects of $\mathrm{TGF} \alpha$, a factor structurally and functionally similar to EGF and which competes with EGF for binding to the same receptor on the surface of epithelial cells, ${ }^{14}$ also showed that mitogenic concentrations of this peptide stimulated basal pepsinogen secretion (Table I).

EGF also potentiated histamine and db-cAMP stimulated pepsinogen secretion. As previously shown, ${ }^{11} 120 \cdot 1 \mathrm{mM}$ concentrations of histamine significantly stimulated pepsinogen secretion from dispersed human peptic cells (Table I). When $0 \cdot 1 \mathrm{nM}$ EGF was combined with histamine and db-cAMP, pepsinogen secretion was stimulated in an additive manner (Fig 2). CCK-OP dose dependently increased pepsinogen secretion from dispersed human peptic cells. The addition of EGF further increased pepsinogen secretion in CCK stimulated cells and such an effect was in addition to that induced by CCK alone (Fig 3). However, EGF (100 nM-0.1 nM) did not increase pepsinogen secretion in acetylcholine $(\mu M)$ stimulated cells $(1.85(0.3) \%$ v $2.31(0.4)$ $2(0.35) \% \mathrm{n}=6)$. The effect of $0.1 \mathrm{nM} \mathrm{TGF} \alpha$ was also tested in combination with db-cAMP and CCK obtaining similar results to those presented with EGF (data not shown).

TABLE I Pepsinogen secretion by isolated human peptic cells incubated for 30 minutes with various secretagogues

\begin{tabular}{lll}
\hline Agonist & Concentration & $\begin{array}{l}\Delta \text { Pepsinogen secretion } \\
(\% \text { total-basal/30 min })\end{array}$ \\
\hline CCK-OP & $10^{-8} \mathrm{M}$ & $2 \cdot 6(0 \cdot 58)$ \\
Acetylcholine & $10^{-7} \mathrm{M}$ & $4 \cdot 9(0 \cdot 9)$ \\
db-cAMP & $10^{-6} \mathrm{M}$ & $1 \cdot 85(0 \cdot 3)$ \\
& $10^{-5} \mathrm{M}$ & $2 \cdot 7(0 \cdot 5)$ \\
EGF & $10^{-4} \mathrm{M}$ & $2 \cdot 2(0 \cdot 6)$ \\
& $10^{-3} \mathrm{M}$ & $4 \cdot 32(1 \cdot 02)$ \\
& $10^{-10} \mathrm{M}$ & $1 \cdot 3(0 \cdot 15)$ \\
TGF $\alpha$ & $10^{-9} \mathrm{M}$ & $2 \cdot 27(0 \cdot 25)$ \\
& $10^{-8} \mathrm{M}$ & $2 \cdot 1(0 \cdot 6)$ \\
& $10^{-11} \mathrm{M}$ & $0 \cdot 98(0 \cdot 18)$ \\
Histamine & $10^{-10} \mathrm{M}$ & $1 \cdot 8(0 \cdot 08)$ \\
Gastrin & $10^{-9} \mathrm{M}$ & $1 \cdot 66(0 \cdot 4)$ \\
& $10^{-4} \mathrm{M}$ & $1 \cdot 8(0 \cdot 3)$ \\
& $10^{-6} \mathrm{M}$ & $1 \cdot 5(0 \cdot 2)$ \\
\hline
\end{tabular}

Each value is the mean (SEM) of four to 12 separate experiments. Basal secretion in experiments $=4 \cdot 34(0 \cdot 89)$ $5 \cdot 34(0 \cdot 67) \%$. All values $=\mathrm{p}<0 \cdot 05 v$ basal secretion. $\mathrm{CCK}-\mathrm{OP}=$ cholecystokinin-8; TGF $=$ transforming growth factor; $E G F=$ epidermal growth factor. 


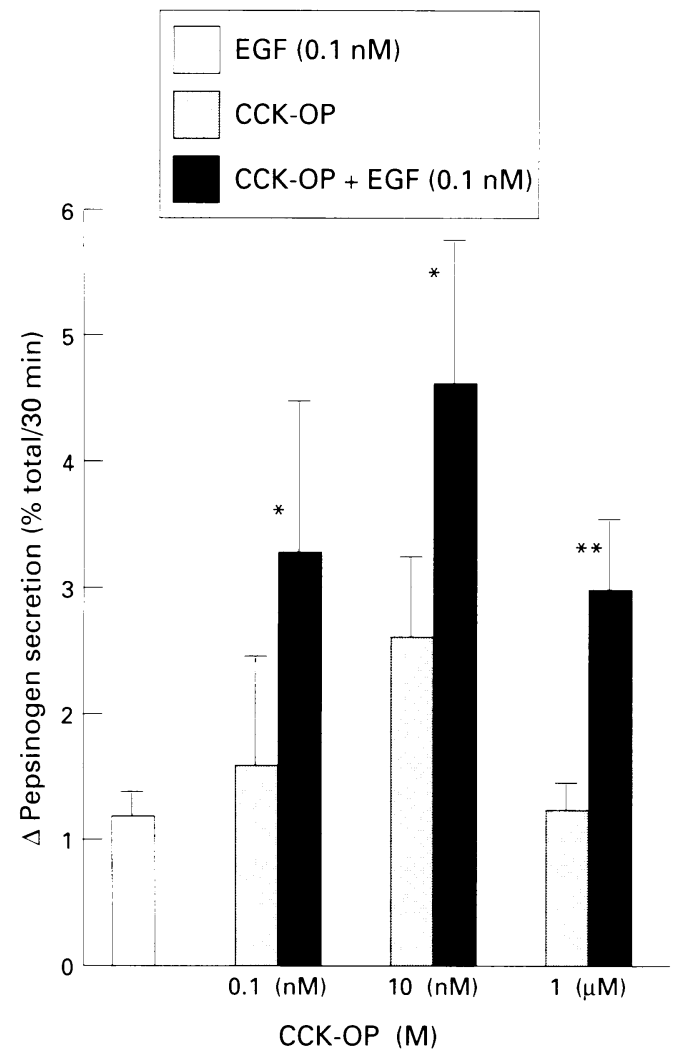

Figure 3: Epidermal growth factor (EGF) increased $C C K-O P$ stimulated pepsinogen secretion from dispersed human peptic cells. The combination of these agents produced additive pepsinogen secretion responses. $\left({ }^{*} p<0.05\right.$ and $\left.\star^{*}<<0 \cdot 01\right)$. The effect of $C C K-O P$ on basal secretion was also significant $(\dagger p<0.05$ and $\neq p<0.01$ ). Results are presented as means (SEM) of six separate experiments. Basal secretion $=4 \cdot 8(0 \cdot 71) \%$.

To study whether the effects of EGF on pepsinogen secretion were non-specific or dependent on the activation of a cell surface receptor the cells were resuspended in the presence of two different concentrations (1:500 and 1:100 dilution) of an immunospecific antibody against human EGF receptor $(100 \mu \mathrm{g} / \mathrm{ml})$ and then stimulated with EGF. In these conditions the effect of EGF on basal pepsinogen secretion was partially or completely inhibited by both concentrations of the antibody respectively (Fig 4A). EGF effects on pepsinogen secretion were also inhibited $(62 \%)$ by genistein, a membrane cytosolic tyrosine kinase inhibitor (Fig 4A). In a different set of experiments, tyrphostin-25, an inhibitor of EGF receptor tyrosine kinase activity, induced a small increase in pepsinogen secretion but also prevented the higher increase obtained with EGF (Fig 4B). However, genistein and tyrphostin at the same concentrations used in previous experiments did not significantly affect CCK stimulated pepsinogen secretion $(2.03(0.5)$ with $10 \mu \mathrm{M}$ genistein+10 nM CCK-OP and $2 \cdot 29(0 \cdot 29)$ with $10 \mu \mathrm{M}$ tyrphostin+10 (nM) CCK-OP $v$ $2 \cdot 6(0.58)$ with CCK-OP alone; $n=4)$.

Effects of interleukin $1 \beta$ on basal and stimulated pepsinogen secretion from isolated human peptic cells Unlike EGF, neither high nor low concentrations of IL $1 \beta$ induced any significant effect on basal pepsinogen secretion from isolated
A
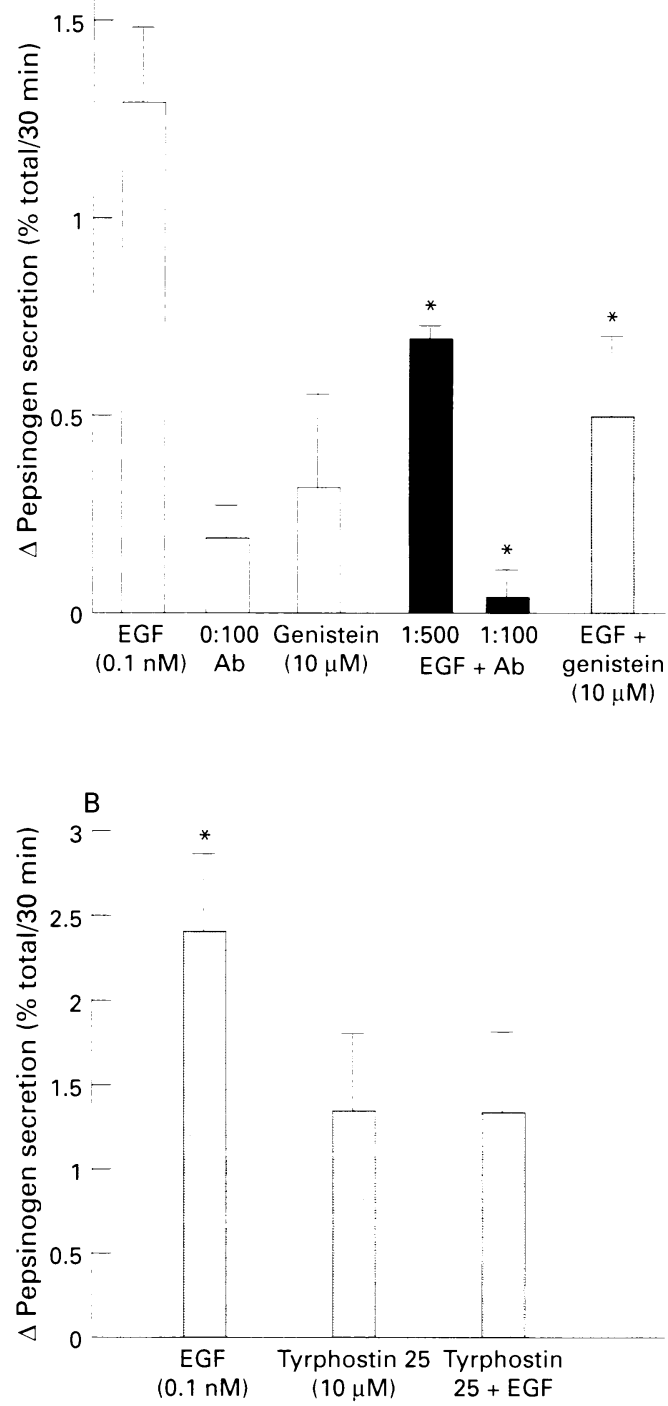

Figure 4: (A) The effect of epidermal growth factor (EGF) on basal pepsinogen secretion was completely inhibited with a human immunospecific antibody $(A b)$ against the $E G F$ receptor at $1: 100$ concentration $\left({ }_{p}<0.05\right)$ and it was partially $(62 \%)$ inhibited at 1:500 concentration. Genistein at $10 \mu \mathrm{M}$ concentration also inhibited EGF stimulated pepsinogen secretion $\left({ }^{*} p<0 \cdot 05\right)$. EGF effect on basal pepsinogen secretion was statistically significant with respect to control experiments $(\dagger p<0 \cdot 01)$. Results are presented as means (SEM) of four to seven separate experiments respectively. Basal secretion $=4.84(0.5) \%$ (B) Tyrphostin-25, an inhibitor of the EGF receptor tirosine kinase activity, induced an increase in basal pepsinogen secretion but inhibited the greater stimulation induced by $n M E G F$. Results are presented as means (SEM) of seven separate experiments. Basal secretion= $5.67(0.71) \%\left({ }^{*}<<0.05 \mathrm{v}\right.$ peptic cells incubated alone).

peptic cells. Neither did IL $1 \beta$ significantly affect CCK or acetylcholine stimulated peptic cells. However, IL $1 \beta$ completely inhibited maximally histamine stimulated pepsinogen secretion (Table II). In a different set of experiments, both submaximally $(0 \cdot 1 \mathrm{mM})$ and maximally ( $\mathrm{mM}$ ) db-cAMP stimulated pepsinogen secretions were dose dependently inhibited by IL $1 \beta$ (Fig 5 ).

\section{Discussion}

In this study, it has been shown for the first time that EGF stimulates basal pepsinogen secretion from isolated human peptic cells 
TABLE II Effects of interleukin $1 \beta$ (IL $1 \beta$ ) on basal and stimulated pepsinogen secretion by isolated human peptic cells

\begin{tabular}{lll}
\hline & $\begin{array}{l}\text { Agonist alone } \\
\text { APepsinogen secretion } \\
\text { Agent }\end{array}$ & $\begin{array}{l}\text { Agonist }+ \text { IL 1 } 1 \\
\text { (\%epsinogen secretion } \\
(\% \text { total-basal/30 min })\end{array}$ \\
\hline IL 1 (1 IU) & $0 \cdot 6(0 \cdot 19)$ & - \\
$10^{-6}$ M ACH & $1 \cdot 85(0 \cdot 3)$ & $0 \cdot 83(0 \cdot 14)$ \\
$10^{-6}$ M CCK-OP & $2 \cdot 6(0 \cdot 5)$ & $1 \cdot 39(0 \cdot 28)$ \\
$10^{-4}$ M HIS & $1 \cdot 81(0 \cdot 5)$ & $0 \cdot 3(0 \cdot 1)^{\star}$ \\
$10^{-4}$ M db-cAMP & $1 \cdot 89(0 \cdot 6)$ & $0 \cdot 06(0 \cdot 3)^{\star}$ \\
\hline
\end{tabular}

Basal secretion $=6.4(0 \cdot 29)$. Each value is the mean (SEM) of four to seven separate experiments. ${ }^{\star} \mathrm{p}<0.05 v$ agonist alone. $\mathrm{ACH}=$ acetylcholine, HIS=histamine, CCK-OP=cholecystokinin-8.

and that IL 1 inhibits stimulated pepsinogen secretion dependent on cAMP mobilisation in the same experimental model. Parenteral EGF reduces acid secretion stimulated by histamine, pentagastrin carbachol, and insulin induced hypoglycaemia in rats, dogs, and monkeys. ${ }^{815} 16$ In vitro studies in Ussing chambers, in isolated gastric glands or in isolated parietal cells from rats, guinea pig, frog, and dogs have also shown that EGF inhibits acid secretion stimulated by different agonists. ${ }^{17-21}$ In these studies, species differences have been reported, suggesting that data from one species cannot be fully extrapolated to others (for example, humans). Unlike gastric acid, we have found that EGF stimulates basal pepsinogen secretion from dispersed human peptic cells. This effect was still present when pepsinogen secretion was maximally or submaximally stimulated, or both, with CCK, histamine, and db-cAMP. These effects also seem to be induced by TGF $\alpha$, a factor that is structurally and functionally similar to EGF and competes with EGF for binding to the same receptor on the surface of epithelial cells. ${ }^{14}$ Although acid and pepsinogen responses to different stimuli are thought to be similar,

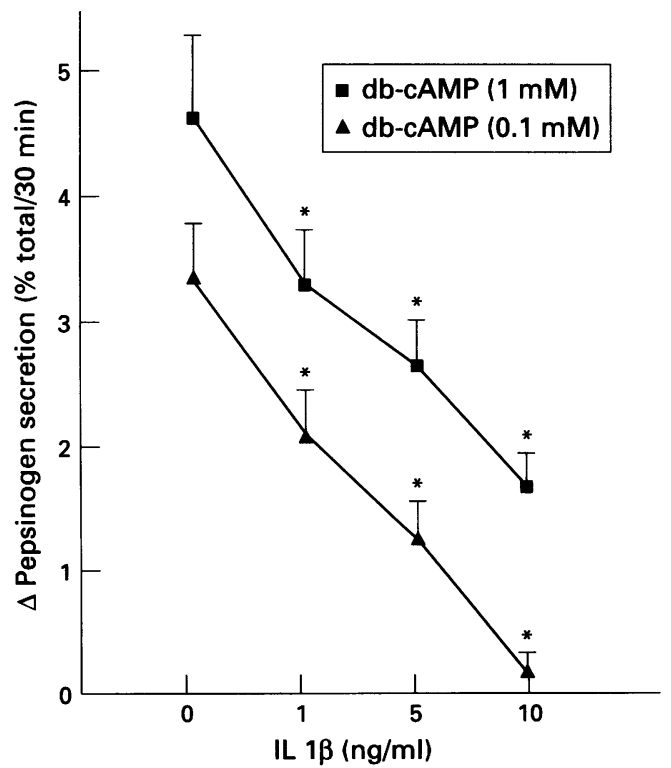

Figure 5: Interleukin $1 \beta$ dose dependently inhibited both submaximally and maximally $d b-c A M P$ stimulated pepsinogen secretion from dispersed human peptic cells. All values were statistically different versus peptic cells incubated with $d b-c A M P(p<0.05) ; d b-c A M P$ effects on basal secretion were also statistically significant with respect to control experiments $(p<0 \cdot 01)$. Results are presented as means (SEM) of four separate experiments. Basal secretion $=5 \cdot 97(0 \cdot 5) \%$ different and opposite effects of prostaglandins on acid and pepsinogen secretion from isolated canine and human gastric cells had previously been reported that suggests that acid and pepsinogen secretions are not always regulated in parallel. ${ }^{1122}$ As far as we know, the only previous report in the English literature dealing with the effects of EGF on pepsinogen secretion was reported by Miyamoto et al in abstract form. ${ }^{23}$ These authors found that EGF inhibited forskolin and db-cAMP but not carbachol or CCK stimulated pepsinogen secretion in organ culture of small fragments of rabbit gastric mucosa at $0 \cdot 1 \mathrm{mM}$ concentrations. As mentioned above, differences between this study and our results might depend on the experimental model used (fragments of the entire mucosa versus isolated cells) and that EGF effects on human peptic cells could be species specific.

EGF can stimulate the proliferation of epithelial cells at pico to nanomolar concentrations, ${ }^{7}$ but the inhibition of histamine stimulated acid secretion requires nano to micromolar concentrations in different in vitro animal models. ${ }^{18-2024}$ An important finding of our research is that EGF (and also TGF $\alpha$ ) stimulates basal and stimulated pepsinogen secretion at pico to nanomolar concentration, suggesting that EGF can induce this effect on pepsinogen secretion in physiological conditions.

Different intracellular mechanisms have been proposed to explain the effects of EGF on acid secretion and includes the inhibition of cAMP to explain the effects of EGF on histamine stimulated acid secretion in rabbit parietal cells. ${ }^{19}$ Ostrowski et $a l^{20}$ reported that ornithine decarboxylase inhibition blocks the inhibitory effect of EGF on acid production in rat parietal cells, suggesting that EGF acts by means of the induction of ODC activity and the synthesis of polyamines. More recently, Tsunoda et $a l^{25}$ have reported that TGF $\alpha$ inhibited both histamine and carbachol stimulated acid secretion in rabbit parietal cells by a tyrosine kinase dependent pathway. Our results suggest that EGF effects on pepsinogen secretion by dispersed human peptic cells is dependent on binding to EGF receptors because the stimulation was completely inhibited by pre-incubation with a human immunospecific antibody against EGF receptors. The expression of EGF receptors was shown in different gastric cell populations including parietal and chief cells of different animal species and humans. ${ }^{25}{ }^{26} \mathrm{TGF} \alpha / \mathrm{EGF}$ receptor mRNA expression was more intense in parietal cell fractions than in chief cell fractions obtained from the stomach of different animals, ${ }^{26}$ which may suggest the requirement of higher concentrations of EGF to obtain responses from peptic cells. However, this is not the case in this study. Possible explanatory factors include the existence of high affinity EGF binding sites, a higher potency of human recombinant EGF in human peptic cells when compared with the effect of this factor in animal cells, ${ }^{20}$ or an increase of EGF receptor expression as shown in certain pathological conditions. ${ }^{27}$ 
In this system, two different kind of tirosine kinase inhibitors with different specificities including genistein, which is a cell permeant specific inhibitor of both membrane associated and other protein tyrosine kinase activities by means of competition with ATP binding, ${ }^{28}$ and tyrphostin-25, which is an inhibitor of the EGF receptor tyrosine kinase activity, reversed the stimulatory effect of EGF on pepsinogen secretion, suggesting that both receptor and soluble tyrosine kinase activities might be involved in the modulation of EGF on pepsinogen secretion. Furthermore, it seems that this effect is independent of cAMP used pathways because the EGF stimulation of pepsinogen secretion was additive to that obtained after histamine and db-cAMP stimulation. EGF effects on pepsinogen secretion seem dependent on extracellular calcium, because EGF failed to stimulate basal pepsinogen secretion when extracellular calcium was removed from the medium. However, EGF also potentiated CCK but not ACh stimulated pepsinogen secretion, two secretagogues that stimulate pepsinogen secretion through calcium mediated pathways. The reasons for these apparently contradictory results and the enhancement of the EGF potentiation of CCK effect is not clear and requires further and probably extensive research because of the complexity and not fully understood mechanisms of action through which EGF stimulate cells, which suggests that different calcium independent mechanisms might be involved. ${ }^{29} 30$ In this way, we have shown that CCK and EGF have different mechanisms of action because CCK is still able to stimulate secretion in the presence of two different tyrosine kinase inhibitors. Furthermore, we have also seen that, in our system, the pepsinogen secretion obtained with the combination of both CCK and acetilcholine is even higher than the addition of the secretion obtained with each one of them alone (preliminary unpublished data). These interesting data would explain why it is possible that EGF increase the secretion obtained with CCK, and that CCK and acetilcholine may have at least, some independent ways of stimulating pepsinogen secretion in human peptic cells. In other systems, peptides that stimulate enzyme secretion by interacting with CCK receptors can cause maximal stimulation with minimal changes in calcium mobilisation and maximal changes in calcium mobilisation occur with minimal changes in inositol phosphates. ${ }^{31}$

IL 1 is one of the main products of activated macrophages/monocytes and other cell types in both normal and inflamed tissue, including $H$ pylori induced gastritis. At present, interest in this cytokine is growing because of its potential involvement in peptic ulcer disease and other gastroduodenal disorders. ${ }^{32}{ }^{33}$ Furthermore, receptors for acetylcholine, histamine, gastrin, and dopamine in macrophages and plasma cells from the lamina propia of the gastric mucosa have been found, which suggests a potential role for the immune system in the paracrine control of gastric secretion and peptic ulcer disease. ${ }^{4}$ Different animal studies have shown that the administration of IL $1 \beta$, whether intraperitioneal, intravenous or intracisternal, inhibits basal, pentagastrin, and vagally stimulated gastric acid secretion. ${ }^{2} 934$ Preliminary data in isolated murine gastric glands and canine gastric parietal cells suggest that IL $1 \beta$ inhibits histamine and carbachol stimulated acid secretion by acting directly on the parietal cells. ${ }^{33}{ }^{35}$ The effects of IL 1 on pepsinogen secretion are not known. A single report from Okumura and Uhera $^{36}$ in the pylorus ligated rat model showed that both intravenous and, above all, intracisternal IL $1 \beta$ inhibits basal pepsinogen secretion. In this study, we have found that IL $1 \beta$ does not significantly affect either basal or calcium dependent (CCK, acetylcholine) stimulated pepsinogen secretion from dispersed human peptic cells, but it completely inhibits stimulated pepsinogen secretion dependent on cAMP mobilisation (histamine, bd-cAMP). This and other in vivo ${ }^{37}$ and vitro reports on acid secretion ${ }^{33}{ }^{35}$ suggest that IL $1 \beta$ may not only act through the indirect release of substances that will eventually inhibit the gastric secretion but through specific receptors on gastric cells. The intrinsic mechanisms whereby IL $1 \beta$ inhibits pepsinogen secretion are not known. This study suggests that IL $1 \beta$ may interact with secretagogues distal to the site of the catalytic subunit of adenylate cyclase activation. In this way, as shown for other substances, it could induce the inhibition of protein kinase $\mathrm{A}$, through a redistribution of other kinases (for example, PKC) ${ }^{38}$ IL 1 stimulates prostaglandin secretion from different cells, including epithelial cells from the digestive tract. ${ }^{39}$ In vivo studies have suggested that the inhibition of gastric acid secretion by IL $1 \beta$ is a prostaglandin mediated mechanism, because the inhibition of endogenous prostaglandin secretion by indomethacin reverses the effects of IL 1 on gastric acid secretion. ${ }^{937}$ However, this does not seem to be the case for pepsinogen secretion because it has previously been shown ${ }^{1222}{ }^{40}$ that prostaglandins do not inhibit but stimulate pepsinogen secretion by either human or animal peptic cells. Esplugues et $a l^{41}$ showed that IL $1 \beta$ induced inhibition of pentagastrin stimulated acid secretion in the rat involves nitric oxide. This study may suggest the possibility that IL $1 \beta$ effects on pepsinogen secretion also could be a nitric oxide mediated process. However, more recent reports from Fiorucci et $a l^{42}{ }^{43}$ have shown that nitric oxide increases rather inhibits pepsinogen secretion induced by leukotrienes and calcium dependent agonists in guinea pig gastric chief cells. Whether these results can be extrapolated to human peptic cells and whether nitric oxide is involved in the effects of IL $1 \beta$ on pepsinogen secretion is uncertain but deserves further research.

Finally, by using patient material it may be questioned whether long term drug use or the presence of $H$ pylori infection may disturb the response of the cells to different agents. Basal pepsinogen secretion and the response to EGF is similar in samples obtained from either $H$ pylori positive or negative patients in this 
study, which suggests that the presence or absence of previous $H$ pylori infection does not significantly affect the response to EGF. In any case, as previously discussed, ${ }^{11}{ }^{12}$ if the basal status of cells is changed by long term drug use or $H$ pylori infection, the potential differences between experiments and the responses to different secretagogues will largely be eliminated by expressing the results as a percentage of total pepsinogen content with basal secretion subtracted.

The authors are indebted to the patients and the endoscopists J Nerin, F Sopeña, C Aznar, and nursing staff for invaluable work in collecting biopsy samples.

This study was supported by a grant from the Asociacion para Investigaciones Grastoenterologicas de la Provincia de Zaragoza.

1 Hirschowitz BI. Mechanisms of peptic ulcer healing. In: Halter F, Garner A, Tytgat GNJ. eds. Falk Symposium 59. Mechanisms of peptic ulcer healing. Dordrecht, The Netherlands: Kluwer Academic, 1991: 183-94.

2 Uheara A, Namiki M. Immunopathology of ulcer disease. Ann NY Acad Sci 1994: 261-8.

3 Graham DY, Lew GM, Klein PD. Effect of treatment of Helicobacter pylori infection on the long-term recurrence of gastric or duodenal ulcer. Ann Intern Med 1992; 116: $705-8$

4 Mezey E, Palkovits M. Localization of targets for anti-ulcer drugs in cells of the immune system. Science 1992; 258: $1662-5$.

5 Konturek SI, Radecki T, Brzozowski T, Piastucki I, Dembinski A, Dembinska-Kiec A, et al. Gastric cytoprotection by epidermal growth factor. Gastroenterology 1981;81: 438-43.

6 Wright NA, Pike C, Elia G. Induction of a epidermal growth factor-secreting lineage by mucosal ulceration in huma gastrointestinal stem cells. Nature $1990 ; 343: 82-5$.

7 Carpenter G, Cohen S. Epidermal growth factor. $7 \mathrm{Bio}$ Chem 1990; 265: 7709-12.

8 Konturek SJ, Cieszkowski M, Jaworek J, Konturek J, Brzozowski T, Gregory H. Effects of EGF on gastrointestinal secretions. Am $\mathcal{F}$ Physiol 1984; 246 (Gastrointes Liver Physiol): G580-6.

9 Saperas E, Yang H, Rivier C, Tache I. Central action of recombinant interleukin-1 to inhibit acid secretion in rats. Gastroenterology 1990; 99: 1599-606.

10 Bado A, Hervatin F, Lewin ML. Pharmacological evidence for histamine $\mathrm{H} 3$ receptors in the control of gastric acid secretion in cats. Am $\mathcal{F}$ Physiol 1991; 260 (Gastrointest secretion in cats. $A m \mathcal{F}$
Liver Physiol): G631-5.

11 Lanas AI, Anderson JW, Uemura N, Hirschowitz BI. Effects of cholinergic, histaminergic and peptidergic stimulation on pepsinogen secretion by isolated human peptic cells Scand $\mathcal{F}$ Gastroenterol 1994; 29: 678-83.

12 Lanas A, Nerín J, Esteva F, Sáinz R. Non-steroidal antiinflammatory drugs and prostaglandin effects on pepsinogen secretion by dispersed human peptic cells. Gut 1995; 36: 657-63

13 Masui H, Kawamoto T, Sato JD, Wolf B, Sato G, Mendelsohn J. Growth inhibition of human tumor cells in athymic mice by anti-epidermal growth factor receptor monoclonal antibodies. Cancer Res 1984; 44: 1002-7.

14 Marquardt H, Hunkapiller MW, Hood LE, Todaro GJ Rat transforming growth factor type I: structure and
relation to epidermal growth factor. Science 1984; 223: relation to

15 Gonzales A, Garrido J, Vial JD. Epidermal growth factor inhibits cytoeskeleton-related changes in the surface of parietal cells. F Cell Biol 1981; 88: 108-4.

16 Gulietta A, Lesch CA, Romano M, McClure RW, Coffey RJ. Effect of transforming growth factor- $\alpha$ on gastric acid secretion in rats and monkeys. Dig Dis $S_{c i}$ 1994; 39: 177-82.

17 Chen MC, Amirian DA, Soll AH. Epidermal growth factor (EGF) binding and inhibitory effect on acid secretion on isolated canine parietal cells. Fed Proc 1984; 43: 1073 .

18 Finke U, Rutten M, Murphy A, Silen W. Effects of EGF on acid secretion from guinea pig gastric mucosa: in vitro on acid secretion from guinea pig gastric mucos
analysis. Gastroenterology $1985 ; 88: 1175-82$.
19 Lewis JJ, Goldenring R, Asher VA, Moldin IM. Effects of EGF on signal transduction in rabbit parietal cells. $A m$ f Physiol 1990; 258 (Gastrointest Liver Physiol): G476-83.

20 Ostrowski J, Wojciechowski K, Konturek SJ, Butruk E. Inhibitory effect of EGF on secretory response of rat parietal cells is associated with an induction of ODC. Am F Physiol 1993; 264 (Cell Physiol): C1428-33.

21 Rhodes JA, Tam JP, Finke U, Saunders M, Bernanke J, Silen W, Murphy RA. Transforming growth factor $\alpha$ inhibits secretion of gastric acid. Cell Biol 1986; 83. inhibits

22 Defize J, Hunt RH. Effect of hydrochloric acid and prostaglandins on pepsinogen synthesis and secretion in canine gastric chief cell monolayer cultures. Gut 1989; 30 774-81.

23 Miyamoto TM, Itoh $M$, Yokoyama $\mathrm{Y}$, Imai $\mathrm{S}$, Joh $\mathrm{T}$, Noguchi Y, Takeuchi T. Inhibitory effect of epiderma growth factor for pepsinogen secretion in rabbit gastric mucosa. Gastroenterology 1987; 92: 1537A.

24 Shaw GA, Hatt JF, Anderson NG, Hanson PJ. Action of epidermal growth factor on acid secretion by rat isolated parietal cells. Biochem f 1987; 244: 699-704.

25 Tsunoda Y, Modlin IM, Goldenring JR. Tyrosine kinase activities in the modulation of stimulated parietal cell acid secretion. Am 7 Physiol 1993; 264 (Gastrointest Liver Physiol): G351-6.

26 Beauchamp RD, Barnard JA, McCutchen CM, Cherner JA Coffey J. Localization of transforming growth factor-a and its receptor in gastric mucosal cells. $\mathcal{F}$ Clin Invest 1989 84: $1017-23$.

27 Tarnowski A, Stachura J, Durbin T, Sarfeh IJ, Gergely H. Increased expression of epidermal growth factor receptor during gastric ulcer healing in rats. Gastroenterology 1992 102: $695-8$.

28 Akiyama $T$, Ishida J, Nakagawa $\mathrm{S}$, Ogawara $\mathrm{H}$, Watanabe S, Itoh N, et al. Genistein, a specific inhibitor of tyrosine-specific protein kinases. F Biol Chem 1987; 262: 5592-5.

29 Brown KD. The epidermal growth factor/transforming growth factor- $\alpha$ family and their receptors. Eur 7 Gastrogrowth factor- $\alpha$ family and their

30 Van der Geer P, Hunter T, Lindberg RA. Receptor proteintyrosine kinases and their signal-transduction pathways. Ann Rev Cell Biol 1994; 10: 251-337.

31 Rowley WH, Sato S, Huang SC, Collado-Escobar D Beaven MA, Wang L, et al. Cholecystokinin-induced formation of inositol phosphates in pancreatic acini. $A m$ f Physiol 1990; 259: G655-65.

32 Fiocchi C, Binion DG, Katz JA. Cytokine production in the human gastrointestinal tract during inflammation. Cur Opin Gastroenterol 1994; 2: 639-44.

33 Muller MJ, Hunt RH. Cytokines and peptic ulcer disease. Eur 7 Gastroenterol Hepatol 1993; 5 (suppl 3): S69-73.

34 Wallace JL, Cucala M, Mugridge K, Parente L. Secretagogue-specific effects of interleukin-1 on gastric acid secretion. Am 7 Physiol 1991; 261 (Gastrointest Liver Physiol): G559-64

35 Nompleggui $D$, Beinborn $M$, Wolfe $M$. The effect of cytokines on ${ }^{14} \mathrm{C}$-aminopyrine accumulation in isolated canine parietal cells. Gastroenterology 1992; 102: A432.

36 Okumura T, Uheara A, Okamura K, Takasugui Y, Namiki M. Inhibition of gastric pepsin secretion by peripherally or centrally injected interleukin-1 in rats. Biochem Biophys Res Commun 1990; 167: 956-61.

37 Robert A, Olafsson AS, Lancaster C, Zyang WR. Interleukin-1 is cytoprotective, antisecretory, stimulates PGE2 synthesis by the stomach, and retards gastric emptying. Life Sci 1991; 48: 123-34.

38 Ostrowski J, Bomsztyk K. Interaction of signal transduction pathways in mediating acid secretion by rat parietal cells. pathways in mediating acid secre

39 Dinarello CA. IL-1 and IL-1 antagonism. Blood 1991; 77 $1627-52$.

40 Raufman JP, Cosowsky L. Relation of prostaglandininduced increases in cellular cAMP to stimulation of pepsinogen secretion from dispersed chief cells. $\mathcal{F} \mathrm{Cell}$ Physiol 1987; 132: 137-42.

41 Esplugues JV, Barrachina D, Calatayud S, Piqué JM, Whittle BJR. Nitric oxide mediates the inhibition by interleukin- $1 \beta$ of pentagastrin-stimulated rat gastric acid secretion. Br f Pharmacol 1993; 108: 9-10.

42 Fiorucci S, Distrutti E, Santucci L, Morelli A. Leukotrienes stimulate pepsinogen secretion from guinea pig gastric chief cells by a nitric oxide-dependent pathway. Gastroenterology 1995; 108: 1709-19.

43 Fiorucci S, Distrutti E, Chiorean M, Santucci L, Belia S, Fano $\mathrm{G}$, et al. Nitric oxide modulates pepsinogen secretion induced by calcium-mediated agonist in guinea pig gastric chief cells. Gastroenterology 1995; 109: pig gastric 